\title{
Article \\ Extracellular Matrix Remodeling by Fibroblast-MMP14 Regulates Melanoma Growth
}

\author{
Elke Pach ${ }^{1} \mathbb{D}$, Maike Kümper ${ }^{1}$, Julia E. Fromme ${ }^{1,2}{ }^{,}$Jan Zamek $^{1}$, Fabian Metzen ${ }^{3}$, Manuel Koch ${ }^{3} \mathbb{D}$, \\ Cornelia Mauch ${ }^{1}$ and Paola Zigrino ${ }^{1, *(\mathbb{D})}$
}

1 Department of Dermatology and Venereology, Faculty of Medicine and University Hospital Cologne, University of Cologne, 50937 Cologne, Germany; elke.pach@uk-koeln.de (E.P.); maike.kuemper@uk-koeln.de (M.K.); julia.fromme@uk-koeln.de (J.E.F.); jan.zamek@uk-koeln.de (J.Z.); cornelia.mauch@uk-koeln.de (C.M.)

2 Mildred Scheel School of Oncology Aachen Bonn Cologne Düsseldorf (MSSO ABCD), 50937 Cologne, Germany

3 Faculty of Medicine and University Hospital, Institute for Dental Research and Oral Musculoskeletal Biology and Center for Biochemistry, University of Cologne, 50937 Cologne, Germany; fabian.metzen@uk-koeln.de (F.M.); manuel.koch@uni-koeln.de (M.K.)

* Correspondence: paola.zigrino@uni-koeln.de

Citation: Pach, E.; Kümper, M.; Fromme, J.E.; Zamek, J.; Metzen, F.; Koch, M.; Mauch, C.; Zigrino, P. Extracellular Matrix Remodeling by Fibroblast-MMP14 Regulates Melanoma Growth. Int. J. Mol. Sci. 2021, 22, 12276. https://doi.org/ $10.3390 /$ ijms 222212276

Academic Editor: Balázs Margit

Received: 29 September 2021 Accepted: 11 November 2021 Published: 12 November 2021

Publisher's Note: MDPI stays neutral with regard to jurisdictional claims in published maps and institutional affiliations.

Copyright: (C) 2021 by the authors. Licensee MDPI, Basel, Switzerland. This article is an open access article distributed under the terms and conditions of the Creative Commons Attribution (CC BY) license (https:// creativecommons.org/licenses/by/ $4.0 /)$.

\begin{abstract}
Maintaining a balanced state in remodeling the extracellular matrix is crucial for tissue homeostasis, and this process is altered during skin cancer progression. In melanoma, several proteolytic enzymes are expressed in a time and compartmentalized manner to support tumor progression by generating a permissive environment. One of these proteases is the matrix metalloproteinase 14 (MMP14). We could previously show that deletion of MMP14 in dermal fibroblasts results in the generation of a fibrotic-like skin in which melanoma growth is impaired. That was primarily due to collagen I accumulation due to lack of the collagenolytic activity of MMP14. However, as well as collagen I processing, MMP14 can also process several extracellular matrices. We investigated extracellular matrix alterations occurring in the MMP14-deleted fibroblasts that can contribute to the modulation of melanoma growth. The matrix deposited by cultured MMP14-deleted fibroblast displayed an antiproliferative and anti-migratory effect on melanoma cells in vitro. Analysis of the secreted and deposited-decellularized fibroblast's matrix identified a few altered proteins, among which the most significantly changed was collagen XIV. This collagen was increased because of post-translational events, while de novo synthesis was unchanged. Collagen XIV as a substrate was not pro-proliferative, pro-migratory, or adhesive, suggesting a negative regulatory role on melanoma cells. Consistent with that, increasing collagen XIV concentration in wild-type fibroblast-matrix led to reduced melanoma proliferation, migration, and adhesion. In support of its anti-tumor activity, enhanced accumulation of collagen XIV was detected in peritumoral areas of melanoma grown in mice with the fibroblast's deletion of MMP14. In advanced human melanoma samples, we detected reduced expression of collagen XIV compared to benign nevi, which showed a robust expression of this molecule around melanocytic nests. This study shows that loss of fibroblast-MMP14 affects melanoma growth through altering the peritumoral extracellular matrix (ECM) composition, with collagen XIV being a modulator of melanoma progression and a new proteolytic substrate to MMP14.
\end{abstract}

Keywords: MMP14; proteases; melanoma; collagen; extracellular matrix

\section{Introduction}

Matrix metalloproteinases (MMPs) are calcium-dependent, zinc-containing endopeptidases crucial for tissue remodeling during development and adulthood. They can degrade extracellular matrix (ECM) proteins and thus play an essential role in tissue turnover to maintain tissue homeostasis. Their dysregulation is associated with several pathological conditions such as fibrosis and cancer [1]. Based on their structure and substrate specificity, 
MMPs are classified into six major subgroups: collagenases, gelatinases, stromelysins, matrilysins, and membrane-type MMPs [2]. MMP14 was the first described membraneanchored MMP, identified as a cellular receptor and activator for pro-MMP2 [3]. Besides its role in maintaining tissue homeostasis, MMP14 is up-regulated in many tumors and promotes their progression by regulating cellular processes such as proliferation, migration, and tumor cell invasion [4-6]. The essential role of MMP14 in tissue homeostasis and development has been emphasized in mice with overall MMP14 deletion, which suffer from severe defects in connective tissues, organs function, and bone development, all leading to early death [7-9]. To circumvent premature death and address the cell-specific role of MMP14 in vivo, we have previously used mice carrying a cell-specific MMP14 deletion [10-13]. Deleting MMP14 in dermal fibroblasts (MMP14 ${ }^{\mathrm{Sf}-/-}$ ) highlighted the critical collagenase function of MMP14 in skin homeostasis. Indeed, MMP14 deletion in fibroblasts led to the development of a fibrosis-like skin phenotype [13]. Dermal alterations, collagen I accumulation, and increased tissue stiffness also restrained melanoma growth [14]. In addition to collagen I, likely other collagens were altered around these tumors, as increased hydroxyproline would result from all types of collagens [14]. Collagens are a large superfamily of 28 different types presenting the most abundant proteins in the extracellular matrix of vertebrates. They are functional in maintaining tissue structure, stability, and mechanical properties $[15,16]$ and are regulators of several cellular functions, including proliferation, apoptosis, differentiation, adhesion, and migration [17-22]. In the skin dermis, fibrillar type I and type III collagens represent the major collagens. However, types V, VI, XII, XIV, and XVI are also present in lower amounts [23].

We sought to identify the ECM molecules that are changed in the peritumoral tissue of MMP14 $4^{\mathrm{Sf}-/-}$ mice that contribute to altering melanoma growth. By investigating the matrix deposited by MMP14 ${ }^{\mathrm{Sf}-/-}$ and control fibroblast, we show that collagen XIV is enriched in the peritumoral tissue of $\mathrm{MMP} 14^{\mathrm{Sf}-/-}$ mice and has anti-tumor activity in melanoma cells.

\section{Results}

\subsection{Negative Effect of MMP14 ${ }^{\text {Sf-/- }}$ Fibroblast Matrix on Melanoma Proliferation and Migration}

Extensive deposition of extracellular matrix, with enhanced collagen accumulation, is linked to the growth of many cancers [24-26], although the influence of collagen is diverse on the different types of cancers. Mice lacking MMP14 in stromal fibroblasts $\left(\mathrm{MMP} 14^{\mathrm{Sf}-/-}\right.$ ) display skin fibrosis and reduced melanoma growth due to enhanced collagen I accumulation and increased skin stiffness [13,14]. However, it was unclear whether additional extracellular matrix alterations due to MMP14 deletion in fibroblasts, the primary producer of extracellular matrix in tissues, contribute to the observed effect. To address this, we cultured MMP14 ${ }^{\mathrm{Sf}-/-}$ and control fibroblasts for 14 days, the time necessary for cellular matrix deposition. As observed by Coomassie-stained wells after removing cells, the density of this matrix increased when cells lacked MMP14 (Figure 1a). The increase was quantified in urea-extracted matrices from 6 to 7 independent fibroblasts isolates and displayed a significant difference $(* * p<0.01)$ with values of $16 \pm 0.2$ and $17.6 \pm 0.3 \mu \mathrm{g} / \mathrm{mL}$ by control and MMP14 $4^{\mathrm{Sf}-/-}$ fibroblasts. Cell proliferation of three melanoma cell lines (B16F0, B16F1, and HCmel12) was significantly reduced when seeded on $\mathrm{MMP} 14^{\mathrm{Sf}-/-}$ fibroblast's decellularized matrix compared to the control matrix and cells cultured on serum coating, used as an additional control (Figure 1b and Figure S1).

Further, B16F1 melanoma cells migration on matrix deposited from MMP14 ${ }^{\mathrm{Sf}-/-}$ and MMP1 $4^{\mathrm{Sf}+/+}$ fibroblasts for $24 \mathrm{~h}$, analyzed by a colony outgrowth method, was decreased on MMP14 $4^{\mathrm{Sf}-/-}$ fibroblast matrix compared to control (Figure 1c). After four hours, this delay was detected and most significant at $24 \mathrm{~h}$ (Figure 1c). Collectively, these data indicate that matrix from $\mathrm{MMP} 14^{\mathrm{Sf}-/-}$ fibroblast negatively influences melanoma cell proliferation and migration. 
a

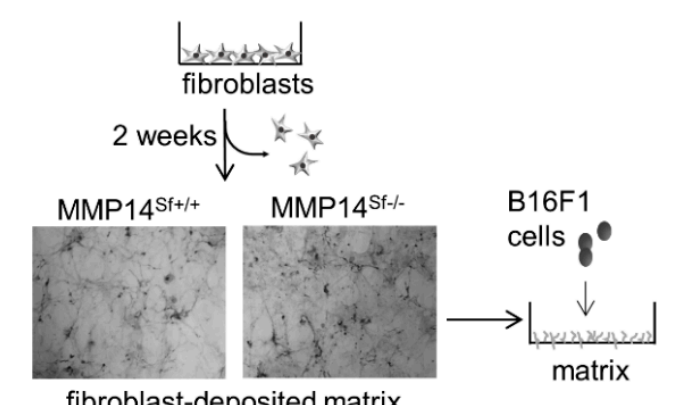

fibroblast-deposited matrix b

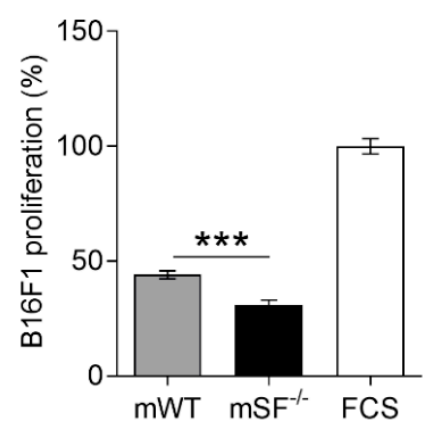

C
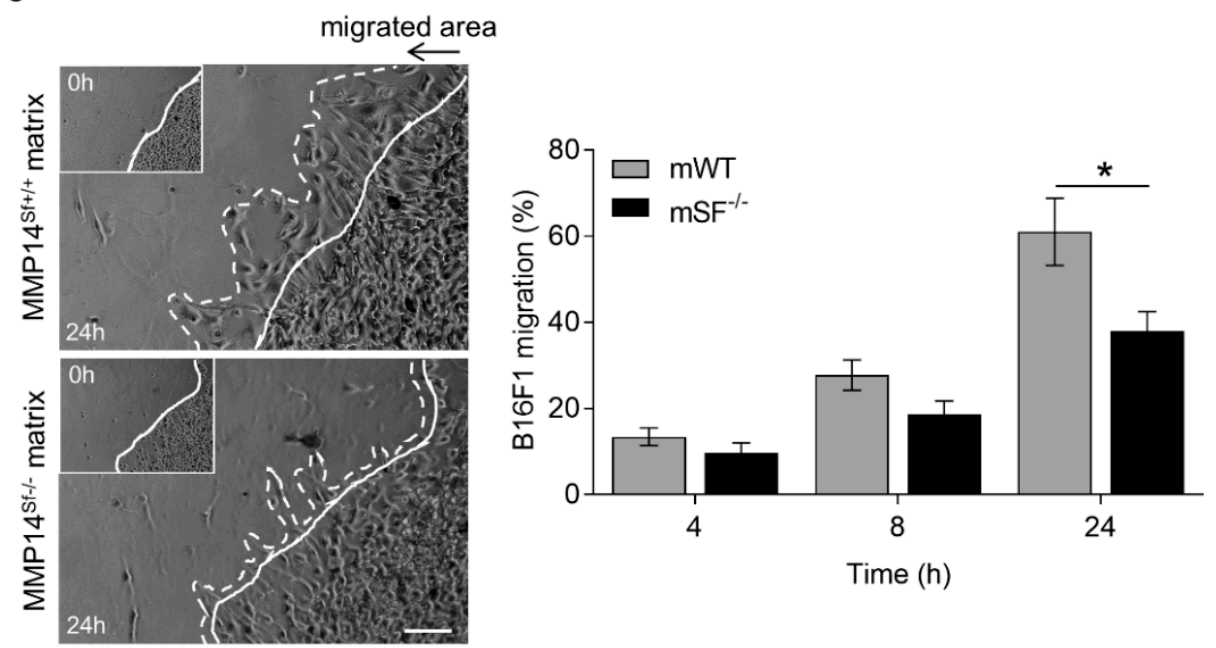

Figure 1. B16F1 cell proliferation and migration on $\mathrm{MMP} 4^{\mathrm{Sf}-/-}$ and $\mathrm{MMP} 14^{\mathrm{Sf}+/+}$ fibroblast matrix. (a) Schematic representation of fibroblast culture to obtain their matrix (picture of Coomassie-stained matrix after fibroblast removal) and seeding B16F1 cells on it. (b) BrdU incorporation measurement of B16F1 cells cultured on fibroblast matrix. (c) Colony outgrowth assay showing melanoma migration on fibroblast matrix (left) and quantification (right). Experiments were repeated three times. $\mathrm{mWT}$ (MMP14 ${ }^{\mathrm{Sf}+/+}$ matrix, control matrix) $n=3 ; \mathrm{mSF}^{-/-}\left(\mathrm{MMP}^{\mathrm{Sf}-/-}\right.$ matrix) $n=3$; continuous line, cell front after $0 \mathrm{~h}$; dashed line, cell front after indicated period of time; ${ }^{*} p<0.05 ;{ }^{* * *} p<0.001$; scale, $100 \mu \mathrm{m}$.

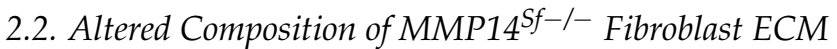

We used an unbiased approach to identify the matrix molecules altered by fibroblasts without MMP14 [12]. To this end, we cultured three independent primary fibroblast populations from each genotype, as described above, and collected both the deposited matrix and supernatants. The matrix composition and the conditioned media were analyzed using mass spectrometry (Figure 2a; Table S1). Among the data obtained, we selected differentially expressed extracellular matrix proteins. At the same time, we excluded cellular proteins that may be residues from decellularization in the accumulated "matrix." However, only five extracellular matrices were significantly altered in the fibroblast matrix and three in the conditioned medium (Figure 2a, stars). Among those, in both matrix and secreted fractions was collagen XIV. Collagen VI and I were also increased, although not significantly, only in the secreted fractions (Figure 2a). As previously observed [12], collagen I was raised in $\mathrm{MMP} 14^{\mathrm{Sf}-/-}$ fibroblast matrix lysates and conditioned medium by immunoblot analysis, but not collagen VI (Figure $2 \mathrm{~b}$ ). Collagen XIV was confirmed to be up-regulated by immunoblot in $\mathrm{MMP} 14^{\mathrm{Sf}-/-}$ fibroblast's matrix and supernatants, as observed in the mass spectrometric analysis (Figure 2a,b). 
a

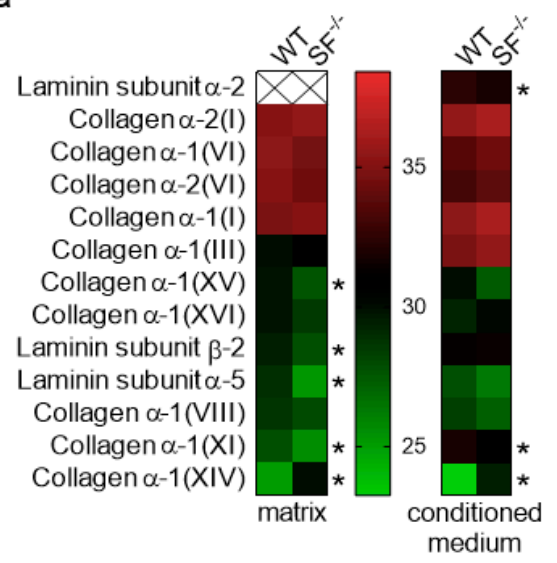

C

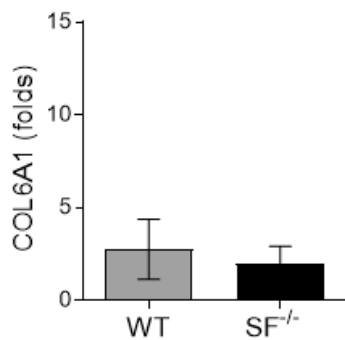

b

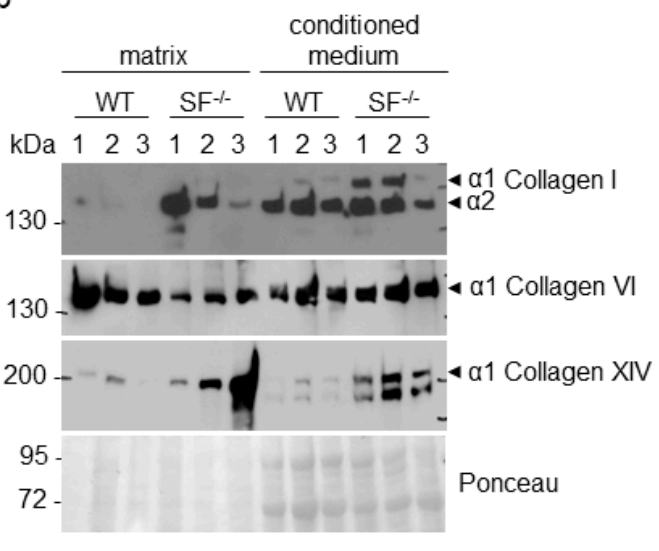

d

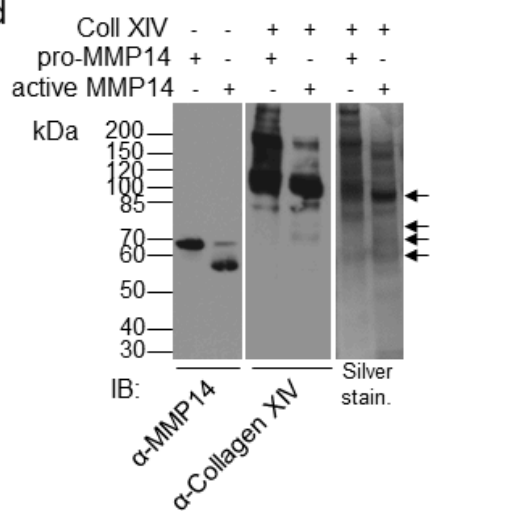

Figure 2. Analysis of MMP14 $4^{\mathrm{Sf}-/-}$ and $\mathrm{MMP} 14^{\mathrm{Sf}+/+}$ fibroblast matrices. (a) Mass Spectrometric and (b) immunoblot analysis of fibroblast matrix and conditioned medium (8\% SDS-PAGE). (c) Transcriptional analysis of fibroblast lysates for collagens VI (COL6A1) and XIV (COL14A1). (d) In vitro processing of recombinant collagen XIV (Coll XIV) and human MMP14 visualized on immunoblot and silver staining (4-12\% Bis-Tris gradient gel). Collagen XIV fragments generated by MMP14 are indicated with black arrows. MMP14 ${ }^{\mathrm{Sf}+/+}(\mathrm{WT}), n=3 ; \mathrm{MMP}^{\mathrm{Sf}-/-}\left(\mathrm{SF}^{-/-}\right), n=3$; pro-MMP14, inactive form of MMP14; ${ }^{*} p<0.05$.

Although MMP14 is an enzyme with pleiotropic substrates and activities, its primary function is ECM processing [27]. To understand whether the enhanced accumulation of collagen in the absence of MMP14 activity is due to de novo synthesis or impaired degradation, we analyzed transcripts in $\mathrm{MMP} 14^{\mathrm{Sf}-/-}$ and control fibroblasts. As observed for collagen type I [13], type VI and XIV mRNA levels were not significantly altered (Figure 2c). While lack of transcripts regulation for collagen VI agrees with the comparable levels of proteins observed in all probes, increased collagen XIV protein was not accompanied by a relative increase in transcripts (Figure 2c). This suggests that enhanced accumulation of collagen XIV results from post-translational events, possibly impaired processing. Because it is not known whether collagen XIV is a substrate for MMP14, we performed an in vitro enzymatic assay using recombinant collagen XIV and MMP14. Active MMP14 processed collagen XIV as visible from the reduction in the full-length molecule at ca. $220 \mathrm{kDa}$. It generated 65 to $80 \mathrm{kDa}$ fragments, absent when MMP14 was supplied as an inactive enzyme (Figure 2d, black arrows). These data indicate that collagen XIV is a substrate of MMP14 and suggest that the increased amounts of collagen XIV in MMP14 ${ }^{\mathrm{Sf}-/-}$ fibroblast matrix and conditioned medium may result from impaired degradation.

\subsection{Collagen XIV Inhibits Pro-Invasive Activities}

The collagen XIV is fibril-associated collagen (FACIT) found in collagen I rich tissues, and it is known to promote fiber assembly and limit lateral growth [28,29]. Fibrotic lungs 
contain high collagen I and enhanced collagen XIV expression [30,31], and in liver cancer, collagen XIV contributes to maintaining the self-renewal of cancer stem cells [32]. In human skin, collagen type XIV is found underneath the sub-epidermal space and in the dermis, whereas in adult mouse skin, it is detected at low levels in the dermis [29,33]. However, little is known regarding its function in cancer and, in particular, in melanoma. To investigate the biological role of this collagen and its increase in melanoma, we used various in vitro approaches. To analyze its role in melanoma cell proliferation, we coated tissue culture plates with low $(1 \mu \mathrm{g} / \mathrm{mL})$ and high $(10 \mu \mathrm{g} / \mathrm{mL})$ concentrations of collagen XIV or FCS (positive control) and seeded melanoma cells. After $24 \mathrm{~h}$, proliferation was analyzed using the BrdU incorporation method. When grown on collagen XIV, independently of the concentration, melanoma cell proliferation was low compared to FCS (Figure 3a). When collagen XIV was added to FCS, melanoma cell growth on the control substrate was reduced (Figure 3b). Thus, collagen XIV does not support proliferation and exerts an inhibitory effect when supplied to pro-proliferative substrates. This is further underscored by the experiment showing that when added to the pro-proliferative matrix deposited by control (WT) fibroblasts, collagen XIV inhibited proliferation of melanoma cells to a level comparable to that detected on matrix from MMP14 ${ }^{\mathrm{Sf}-/-}$ fibroblasts $\left(\mathrm{mSF}^{-/-}\right.$, Figures $3 \mathrm{c}$ and S2a,b). This may contribute to explaining the reduced melanoma proliferation detected on the $\mathrm{MMP} 14^{\mathrm{Sf}-/-}$ fibroblasts matrix, which was rich in collagen I and XIV (Figure 1c).

a

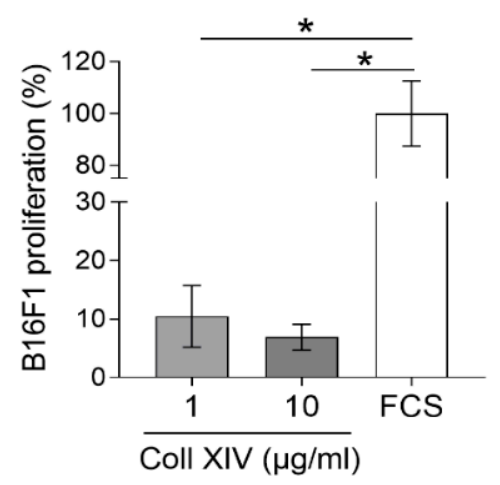

C

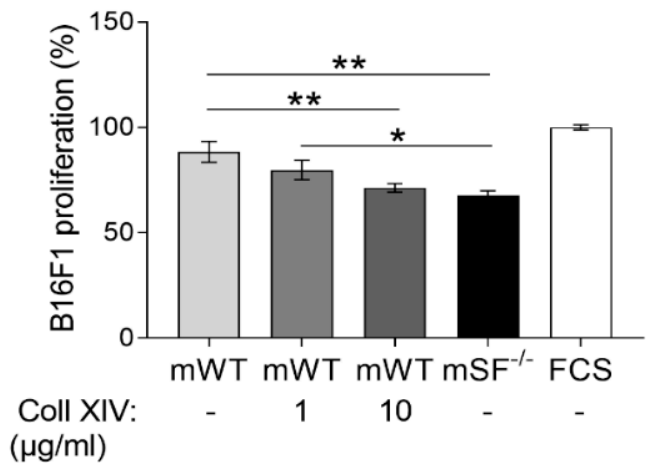

b

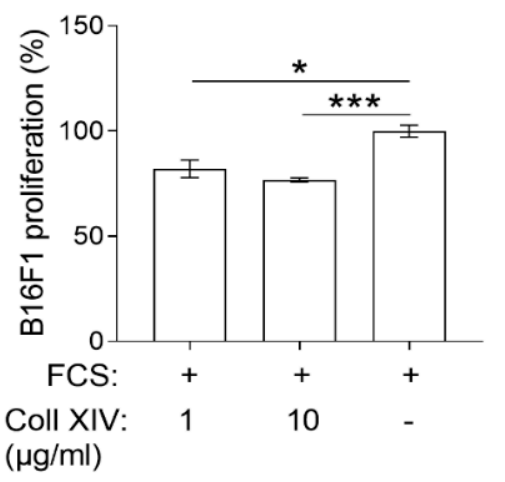

Figure 3. Melanoma cells proliferation on collagen XIV coatings. BrdU incorporation analysis of B16F1 cells cultured on (a) collagen XIV (Coll XIV) (1 to $10 \mu \mathrm{g} / \mathrm{mL}$ ) and (b) on serum (FCS) alone and in combination with collagen XIV (1 to $10 \mu \mathrm{g} / \mathrm{mL}$ ). (c) Proliferation was measured in cells cultured on matrix from control fibroblasts (mWT) alone or with the addition of collagen XIV (1 to $10 \mu \mathrm{g} / \mathrm{mL}$ ) and MMP14 $4^{\mathrm{Sf}-/-}\left(\mathrm{SF}^{-/-}\right)$fibroblasts. Experiments were repeated three times. $\mathrm{mWT}\left(\mathrm{MMP} 14^{\mathrm{Sf}+/+}\right.$ matrix, control matrix), $n=3 ; \mathrm{mSF}^{-/-}\left(\mathrm{MMP}^{\mathrm{Sf}-/-}\right.$ matrix), $n=3 ;{ }^{*} p<0.05$; ${ }^{* *} p<0.01 ; * * * p<0.001$. 
Comparably, out-migration of melanoma cells from a colony seeded on the MMP14 $4^{\mathrm{Sf}+/+}$ fibroblasts matrix supplemented with collagen XIV $(10 \mu \mathrm{g} / \mathrm{mL})$ was significantly reduced compared to the untreated control matrix (Figure 4).
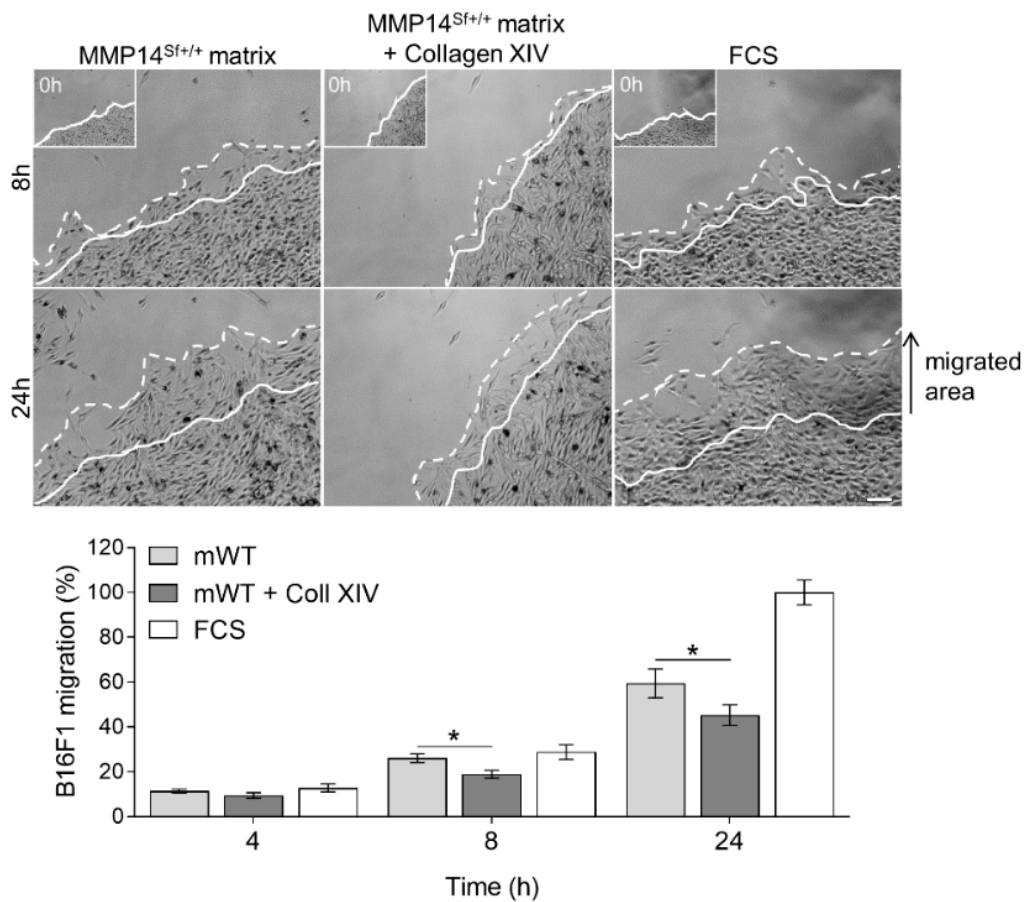

Figure 4. B16F1 cell migration on $\mathrm{MMP} 14^{\mathrm{Sf}+/+}$ fibroblast matrix enriched with collagen XIV. Colony outgrowth assay on MMP14 ${ }^{\mathrm{Sf}+/+}$ fibroblast matrix (mWT) containing $10 \mu \mathrm{g} / \mathrm{mL}$ collagen XIV (Coll XIV). The FCS-coated surface was used as a control. Below is the quantification in the percentage of the migrated area. Experiments were repeated three times. $\mathrm{mWT}\left(\mathrm{MMP} 14^{\mathrm{Sf}+/+}\right.$ matrix), $n=3$; FCS, $n=3$; a continuous line marks the cell border at time $0 \mathrm{~h}$ (this time point is shown in the insert); dashed line, cells border after indicated period of time; ${ }^{*} p<0.05$; scale: $100 \mu \mathrm{m}$.

The negative effect of collagen XIV in the matrix from wild-type fibroblasts during melanoma cell migration prompted us to investigate whether cells recognize and adhere well to collagen XIV. We performed an adhesion assay using collagen XIV as a substrate. Compared to the fibronectin control, the results show that cells did not adhere well to collagen XIV at a one $\mu \mathrm{g} / \mathrm{mL}$ concentration. Surprisingly, this was significantly diminished at higher collagen concentrations $(10 \mu \mathrm{g} / \mathrm{mL}$ ) (Figure $5 \mathrm{a})$. In agreement with these data, adhesion of melanoma cells on matrix deposited from MMP14 $4^{\mathrm{Sf}+/+}$ fibroblasts supplemented with collagen XIV was significantly reduced and reached levels similar to those detected on the MMP14 $4^{\mathrm{Sf}-/-}$ matrix (Figure $5 \mathrm{~b}$ ).

Collectively these data indicate that collagen XIV is not supportive of melanoma cell proliferation and migration, which are principle events of invasion.

\subsection{Collagen XIV Is Accumulated in Melanoma Grown in Fibrotic Skin}

Tumor grafting experiments with B16F1 cells, which were injected intradermally into the flank of MMP14 ${ }^{\mathrm{Sf}-/-}$ and control mice, showed reduced tumor growth in the absence of fibroblast-MMP14 as compared to controls [14]. The numbers of metastasis were not altered, but vascularization by blood and lymphatic vessels was decreased. Moreover, tumor cell proliferation of MMP14 ${ }^{\mathrm{Sf}-/-}$ mice was reduced compared to MMP14 ${ }^{\mathrm{Sf+}++}$ [14]. In the peritumoral tissue of MMP14 ${ }^{\mathrm{Sf}+/+}$ mice, we detected a collagen XIV rich area juxtaposed to the tumor, while the remaining stroma signal intensity was lower (Figure 6). On the contrary, in tumor sections from the MMP1 $4^{\mathrm{Sf}-/-}$ mice, collagen XIV was detected intensely in peritumoral areas, and overall in the dermis (Figure 6), with some positivity 
extending within the melanoma $(\mathrm{t})$. Those observations were confirmed by quantifying collagen XIV signal intensity in peritumoral areas (Figure 6 graph).
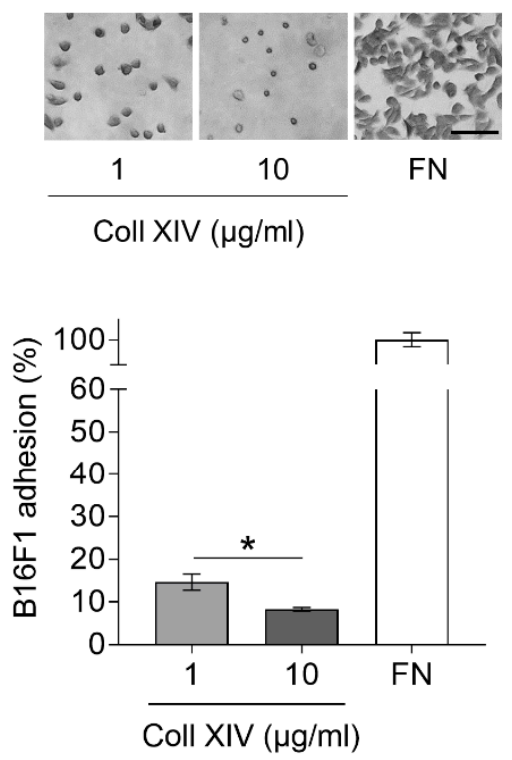

$\mathrm{b}$
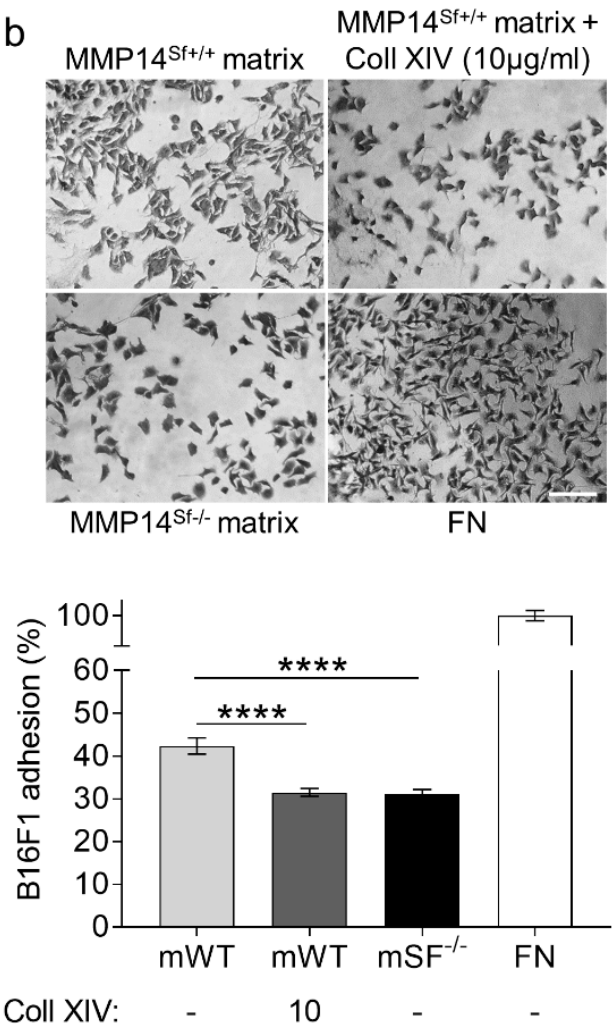

$(\mu \mathrm{g} / \mathrm{ml})$

Figure 5. Analysis of B16F1 cell adhesion on collagen XIV coating and fibroblast matrix. (a) Melanoma adhesion assay on collagen XIV (Coll XIV) coatings $(1 \mu \mathrm{g} / \mathrm{mL} ; 10 \mu \mathrm{g} / \mathrm{mL}),(\mathbf{b})$ wildtype fibroblast matrix (mWT), in combination with $10 \mu \mathrm{g} / \mathrm{mL}$ collagen XIV (mWT + Coll XIV) and MMP14 ${ }^{\mathrm{Sf}-/-}$ matrix $\left(\mathrm{mSF}^{-/-}\right)$. Fibronectin $(\mathrm{FN})$ was used as positive control. Experiments were repeated three times. mWT (MMP14 ${ }^{\mathrm{Sf}+/+}$ matrix, control matrix), $n=3, \mathrm{mWT}+$ Coll XIV, $n=3 ; \mathrm{mSF}^{-/-}$ (MMP14 ${ }^{\mathrm{Sf}-/-}$ matrix), $n=3 ;^{*} p<0.05 ; * * * * 00.0001$; scale, $100 \mu \mathrm{m}$.
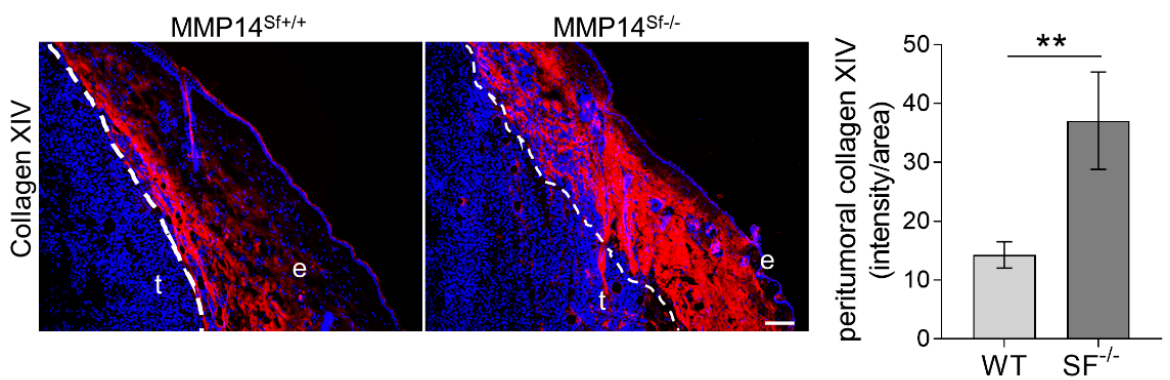

Figure 6. Collagen XIV expression in mouse melanoma. Immunofluorescence staining of collagen XIV (red) and DAPI (blue) in melanoma from MMP14 ${ }^{\mathrm{Sf}+/+}$ and $\mathrm{MMP} 14^{\mathrm{Sf}-/-}$ mice. The graph represents quantified signal intensity per area measured within peritumoral tissue $(100 \mu \mathrm{m}$ radius from the tumor). MMP14 ${ }^{\mathrm{Sf}+/+}(\mathrm{WT}), n=6 ; \mathrm{MMP}^{\mathrm{Sf}-/-}\left(\mathrm{SF}^{-/-}\right), n=5 ; \mathrm{t}$, tumor; e, epidermis. ** $p<0.01$; scale, $100 \mu \mathrm{m}$.

\subsection{Collagen XIV Expression in Human Tissue}

We showed that increased collagen I [14] and XIV negatively influence melanoma growth in mice when fibroblast-MMP14 is deleted. While the expression of collagen I in melanoma has been described [34], there are no previous studies analyzing collagen XIV 
expression in human melanoma. To investigate collagen XIV in melanoma, we performed immunostaining in human tissue samples of benign nevi and melanoma and further investigated MMP14 expression.

The characteristics of the patients' cohort used are shown in Table S2. Collagen XIV in nevi was strongly expressed throughout the dermis and was more intense and packed in areas surrounding the nests of melanocytic nevi (yellow arrowheads, Figure 7). In contrast, the peritumoral areas of melanoma showed a lower expression of collagen XIV (white arrowheads, Figure 7). Quantification of the staining intensity in tissues shows a reduction of collagen XIV expression in melanoma (Figure 7). Correlating with a direct function of MMP14 on collagen XIV processing, peritumoral areas of melanoma displayed a high expression of MMP14 (s in Figure 7) compared to stromal areas around the melanocytic nests of nevi.
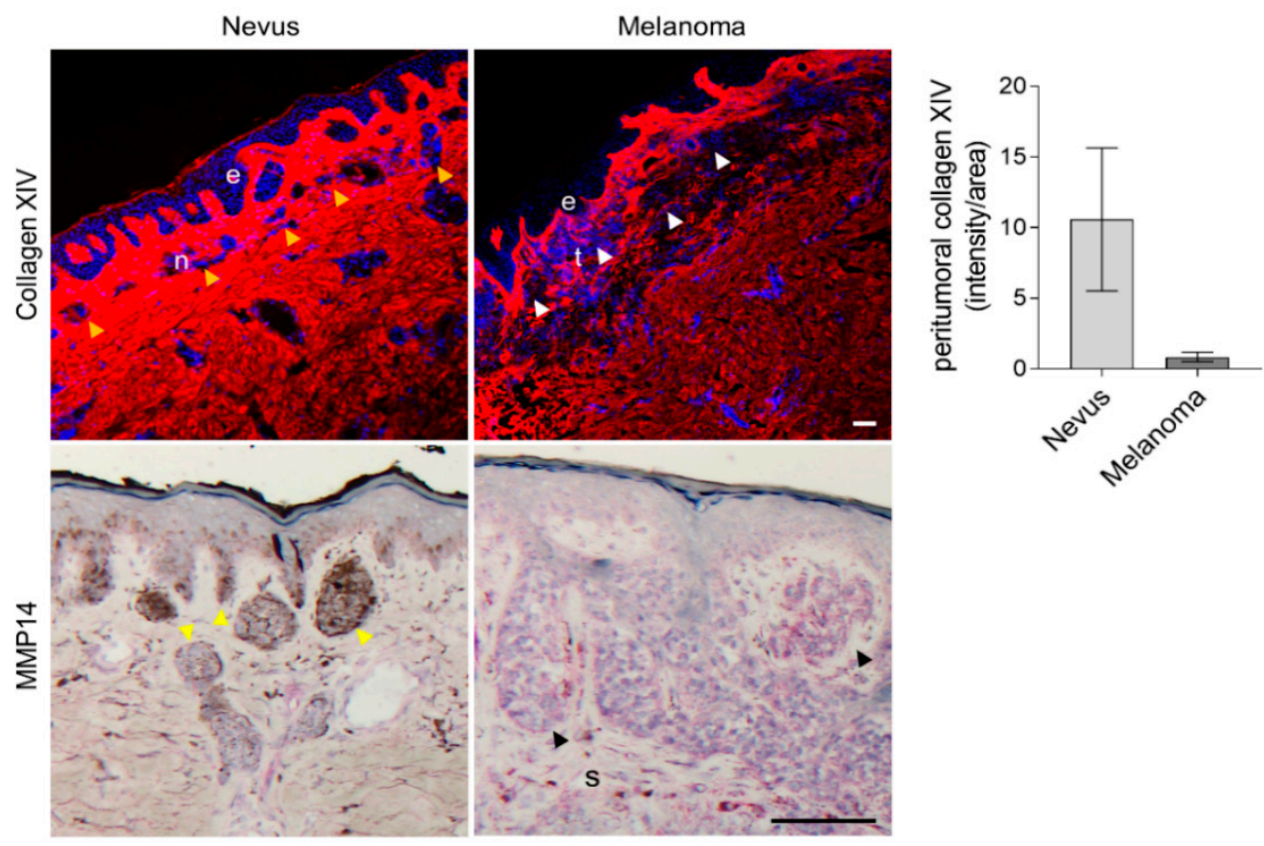

Figure 7. Analysis of collagen XIV and MMP14 expression in human tissue samples. Immunofluorescence detection of collagen XIV (red) and immunohistochemical staining for MMP14 in human nevi and melanoma. The nuclei are in blue (DAPI). Average collagen XIV signal intensity per area is shown on the left. Yellow arrowheads, nests of melanocytic nevi; white/black arrowheads, cutaneous melanoma nests; e, epidermis; $\mathrm{n}$, nevus; $\mathrm{t}$, tumor; s, stroma; scale, $100 \mu \mathrm{m}$.

Thus, the expression of collagen XIV inversely correlates to melanoma progression, and MMP14 expression in these tissues [35] hints at a suppression function for this protein in the transition from benign nevus to malignant melanoma.

\section{Discussion}

Tumor growth depends on events such as cell proliferation, migration, and invasion regulated by tumor cell-autonomous and cell-extrinsic mechanisms modulated by the interaction with the surrounding tumor microenvironment. Enhanced deposition and crosslinking of collagen, the major component of the ECM, and the resulting increased stiffness has been implicated to have a regulatory function in the progression of several tumor types $[25,26]$. Increased collagen density and high stiffness enhanced the proliferative state of melanoma [36]. On the contrary, several in vitro studies, including ours [14], indicate a negative role of high tissue stiffness and fibrillar collagen concentration on melanoma cell growth and migration [37-40]. In line with these findings, we also found reduced melanoma growth in vivo when collagens were increased in the dermis due to MMP14 deletion in fibroblasts or by bleomycin induction of fibrotic lesions formation [14]. 
However, apart from alterations in collagen I, we did not analyze whether additional modifications in the peritumoral matrix of the MMP14 $4^{\mathrm{Sf}-/-}$ also restrained melanoma growth. In vitro, we detected growth inhibition by culturing murine melanoma cells on matrices produced by MMP14-deficient fibroblasts, which macroscopically displayed enhanced matrix deposition. Although we did not find in vivo or ex vivo differences in the migratory capacity of melanoma cells in the dermis from $\mathrm{MMP}_{1} 4^{\mathrm{Sf}-/-}$ mice, in vitro, we detected reduced melanoma migration on matrices produced by MMP14-deficient fibroblasts. We can envision that the discrepancies between in vitro, in vivo, or ex vivo reside in the three-dimensional structure in which the cells are located in the last two systems. Thus, in vitro in a 2D environment, they rely more on integrin-based ECM adhesion and proteolysis [41-43]. Cells can also engage in the amoeboid migration mode in a three-dimensional network where neither integrins nor the formation of focal adhesions and proteolysis is involved [44].

Aiming to identify the different matrix compositions in the absence of fibroblastsderived MMP14, we have used an unbiased approach and limited our search to the extracellular environment by decellularizing the sample's previous analysis. We found in deposited or secreted proteins by fibroblasts in culture the most significant changes occurring in laminins $(\alpha-5, \beta-2)$ and collagens $(\mathrm{XI}, \mathrm{XV}, \mathrm{XVI})$. Although collagen XI and $\mathrm{XV}$ were down-regulated, only XIV was strongly up-regulated in the matrix and soluble fractions. This enhancement was also detected in vivo in peritumoral areas of melanoma in MMP14 $4^{\mathrm{Sf}-/-}$ mice. Collagen XII and XIV are FACIT collagens that decorate fibrillar collagens, contribute to collagen fibrillogenesis, and are often expressed in tissues of high mechanical stress $[28,33,45]$. However, very little is known regarding the biological function of collagen XIV in cells and cancer in general.

Our investigations show that collagen XIV in vitro was not supportive of melanoma cells' proliferation and could also function as an inhibitor of pro-proliferative matrix molecules. Indeed, if supplied to control fibroblast deposited matrix, collagen XIV was able to reduce the extent of melanoma cell proliferation to levels comparable to those observed on matrix from MMP14 $4^{\mathrm{Sf}-/-}$ cells that contain high amounts of this collagen. In agreement with these findings, previous studies associated collagen XIV expression mainly with differentiated tissues rather than proliferative ones $[46,47]$ and have also shown a negative function on cellular proliferation in several other cell types $[46,48,49]$. Furthermore, global deletion of collagen XIV in mice led to increased cardiomyocytes proliferation, underscoring its negative role on proliferation [50].

Besides its role in proliferation, collagen XIV had a similar function on cell migration. Indeed, adding collagen XIV to the matrix deposited by control fibroblasts reduced cell migration and adhesion. Although these indicate that collagen XIV is a poor adhesive substrate, we did not find altered melanoma migration in an ex vivo invasion system [14], thus suggesting that other proteins may compensate for this in vivo.

The putative role of collagen XIV in melanoma growth is probably not limited to the mouse system. In human benign nevi, we found a strong expression of collagen XIV in areas surrounding the melanocyte nests. In contrast, this was reduced in the peritumoral stroma of malignant melanoma. In agreement with our data and the postulated negative role of collagen XIV on melanoma growth in mice, highly proliferative human melanomas show reduced collagen XIV expression in the adjacent stroma [51]. In the mouse model, the accumulation of collagen XIV can be attributed to the deletion of MMP14 in fibroblasts, leading to reduced proteolytic processing. Here we show that collagen XIV is a new substrate for MMP14. Apart from its degradative activity, it is possible to speculate, although no studies support this, that MMP14 proteolytic activity generates collagen XIV bioactive fragments supportive for melanoma growth. This issue will be a matter of future investigations.

In human tissues, we detected an inverse correlation between collagen XIV and MMP14. We found enhanced expression of collagen XIV around the melanocytic nests of benign nevi with reduced MMP14 expression, whereas around malignant melanomas, 
collagen XIV was low and MMP14 highly expressed. In line with these data and with a negative role of collagen XIV with melanoma progression, in human benign nevi, MMP14 is expressed low and increases with melanoma progression [35]. Importantly, MMP14 belongs to a set of up-regulated genes specifically expressed in the transition from nevi to non-metastatic and metastatic melanoma [52].

In summary, we show that the fibroblast-specific deletion of MMP14 leads to changes in the peritumoral ECM composition modulating melanoma growth. Enhanced accumulation of collagen XIV in the MMP14 ${ }^{\mathrm{Sf}-/-}$ fibroblast matrix does not support cell proliferation and migration, thus reducing melanoma cell proliferation, migration, and adhesion to the fibroblast matrix. Moreover, we identified collagen XIV as a substrate for MMP14, showing that enhanced collagen XIV correlates with reduced melanoma growth in mice. In support of the negative role of collagen XIV on malignancy, in human samples, collagen XIV is decreased upon transition from benign nevus to invasive melanoma.

\section{Materials and Methods}

\subsection{Cell Culture}

B16F1, B16F0 [53], and HCmel12 [54] cells were grown in DMEM medium (+4.5 g/L D-Glucose, L-Glutamine, Thermo Fisher Scientific, Darmstadt, Germany), supplemented with 10\% FCS, $2 \mathrm{mM}$ L-glutamine, $100 \mathrm{U} / \mathrm{mL}$ penicillin, and $100 \mu \mathrm{g} / \mathrm{mL}$ streptomycin. Primary mouse dermal fibroblasts were isolated and cultured as previously described [13]. Cells were routinely tested for mycoplasma (PCR Mycoplasma Test Kit I/C; PK-CA911096; Promocell, Heidelberg, Germany). Fibroblast conditioned medium was prepared by culturing primary fibroblasts in serum-free DMEM for $24 \mathrm{~h}$. The medium was collected and spun down for $5 \mathrm{~min}$ at $315 \times g$ to remove cellular debris. A fibroblast matrix was prepared by culturing primary fibroblasts in complete DMEM with $0.05 \mathrm{~g} / \mathrm{L}$ L-ascorbic acid (Sigma, Taufkirchen, Germany) for 14 days; the medium was changed every $2-3$ days. Fibroblasts were removed from the matrix by adding $20 \mathrm{mM} \mathrm{NH} 4 \mathrm{OH}$ and $0.5 \%$ Triton $\mathrm{X}-100$. The matrix was washed gently with PBS and either collected for further analysis or visualized by staining with $0.25 \%$ Coomassie Brilliant blue (G250, Sigma, Taufkirchen, Germany). Images were recorded using a light microscope equipped with DISKUS 4.50.1638 software. Recombinant collagen XIV was produced as previously described [33]. Wildtype fibroblast matrices and multi-well plates were coated with recombinant collagen XIV $(1 \mu \mathrm{g} / \mathrm{mL}$; $10 \mu \mathrm{g} / \mathrm{mL})$ diluted in PBS, $100 \%$ FCS alone, or in combination with collagen XIV $(1 \mu \mathrm{g} / \mathrm{mL}$; $10 \mu \mathrm{g} / \mathrm{mL}$ ) o/n (overnight) at $4{ }^{\circ} \mathrm{C}$. Potential nonspecific binding sites were blocked with $1 \%$ heat-inactivated BSA for one hour at RT.

\subsection{Cell Migration: Colony Outgrow Assay}

B16F1 cell migration assays were performed as previously described [55]. Briefly, B16F1 cells were treated with $1.6 \mu \mathrm{g} / \mathrm{mL}$ mitomycin-C (M4287, Sigma-Aldrich, Schnelldorf, Germany) in $0.1 \%$ FCS DMEM for $4 \mathrm{~h}$ at $37^{\circ} \mathrm{C}$ to inhibit cell growth. Cells $\left(2 \times 10^{5}\right.$ cells $\left./ \mathrm{ring}\right)$ were seeded on top of the fibroblast matrix, restricted by cloning rings ( $0.5 \mathrm{~mm}$ diameter $)$ and left to adhere for three $h$. After removing the ring, cells were washed with PBS to remove non-adherent cells, and a serum-free medium was added. Cell migration was monitored on an Olympus XM10 microscope (Olympus, Tokyo, Japan) and evaluated with ImageJ software (http:/ / rsb.info.nih.gov /ij; version ImageJ 1.53a, accessed on 1 January 2017).

\subsection{BrdU Incorporation Assay}

Melanoma cell proliferation assays were performed as previously described [14]. Briefly, cells were starved for $24 \mathrm{~h}$ and seeded on pre-coated wells for $24 \mathrm{~h}$. Cellular proliferation was analyzed using the Cell Proliferation ELISA ${ }^{\circledR}$ Kit (Cell Proliferation ELISA, BrdU kit, Cat. No. 11647229 001, Roche Life Science, Penzberg, Germany) according to the manufacturer's instructions. 


\subsection{In Vitro Cleavage Assay}

Recombinant human MMP14 100 ng/ $\mu \mathrm{L}$ (918-MPN, R\&D Systems, Wiesbaden, Germany) was activated using $0.1 \mu \mathrm{g} / \mathrm{mL}$ trypsin (15090046, Thermo Fisher Scientific, Darmstadt, Germany) in $50 \mathrm{mM}$ Tris, $0.15 \mathrm{M} \mathrm{NaCl}, 10 \mathrm{mM} \mathrm{CaCl}, 5 \mu \mathrm{M} \mathrm{ZnCl}_{2}, 0.05 \%$ Brij-35, $\mathrm{pH} 7.5$ for $1 \mathrm{~h}$ at $37^{\circ} \mathrm{C}$. Trypsin was inactivated by adding $1 \mathrm{mM}$ pefablock for $15 \mathrm{~min}$ at RT (31682, Serva, Heidelberg, Germany). Afterward, active MMP14 was diluted in assay buffer ( $50 \mathrm{mM}$ Tris, $3 \mathrm{mM} \mathrm{CaCl}, 1 \mu \mathrm{M} \mathrm{ZnCl}_{2}, \mathrm{pH} 8.5$ ) to a final concentration of $50 \mathrm{ng} / \mu \mathrm{L}$. Active MMP14 (100 ng) was used to cleave $1 \mu \mathrm{g}$ recombinant collagen XIV in assay buffer for $2 \mathrm{~h}$ at $37^{\circ} \mathrm{C}$. Cleavage was confirmed by immunoblot and silver gel staining $(4-12 \%$ Bis-Tris gradient gel) (24612, Thermo Scientific, Asbach, Germany). Proteolytic fragments were further identified by peptide mass fingerprint analysis at the CECAD/CMMC Proteomics Facility at the University of Cologne.

\subsection{Immunoblot}

The fibroblast matrix was solubilized in $8 \mathrm{M}$ Urea, $0.2 \%$ SDS, $0.5 \mathrm{M}$ TEAB, $5 \mathrm{mM}$ TCEP, protease inhibitor, and analyzed as previously described [14]. The nitrocellulose membrane was incubated with the following primary antibodies: rabbit $\alpha$-collagen I, 1:500, (ab21286, Abcam, Cambridge, UK); rabbit anti-collagen VI, a kind gift of Raimund Wagener (Institute for Biochemistry II, Cologne, Germany); rabbit $\alpha$-collagen XIV [33]; and rabbit anti-MMP14 [10]. Membranes were washed three times with PBST for 5 min and incubated for $1 \mathrm{~h}$ at RT with the HRP-conjugated secondary antibody: swine $\alpha$-rabbit (P0217, Dako, Waldbronn, Germany).

\subsection{Preparation of Samples for Proteome Analysis}

Samples for proteome analysis were precipitated with acetone and solved in $8 \mathrm{M}$ urea. Afterward, samples were reduced with $5 \mathrm{mM}$ dithiothreitol (DTT) for $1 \mathrm{~h}$ at $37^{\circ} \mathrm{C}$, alkylated with $40 \mathrm{mM}$ chloroacetamide (CAA) for $30 \mathrm{~min}$ RT, and digested with endopeptidase lys-C for $4 \mathrm{~h}$ at $37^{\circ} \mathrm{C}$. Urea concentration was brought to $2 \mathrm{M}$ with triethylammonium bicarbonate (TEAB), and samples were digested overnight with trypsin at a 1:75 ratio $(w / w)$. Samples were acidified with $1 \%$ formic acid. Salts and impurities were removed by micropurification with stage tips containing 2 layers of SDP-RPS (poly(styrene-divinylbenzene)reversed-phase sulfonate) [56]. Samples were analyzed with a Q-Exactive Plus (Thermo Scientific, Asbach, Germany) mass spectrometer coupled to an EASY nLC 1200 UPLC (Thermo Scientific, Asbach, Germany) at the CECAD/CMMC Proteomics Facility at the University of Cologne, as described earlier [57].

\subsection{Tumor Grafting Experiments}

Tumor grafting experiments were performed as previously [14]. Briefly, B16F1 melanoma cells $\left(0.5 \times 10^{6}\right.$ cells / animal $)$ were injected intradermally into the flank of BL6 MMP14 $4^{\mathrm{Sf}+/+}$, and $\mathrm{MMP} 14^{\mathrm{Sf}-/-}$ mice, and tumor growth was followed over time. The experiment was terminated, and mice were euthanized after tumor sizes reached the maximal allowed tumor size.

\subsection{Immunofluorescence Staining}

Cryosections of mouse melanomas and human tissues were immunostained as previously described [14]. Briefly, cryosections were fixed and permeabilized with ice-cold acetone for $2 \mathrm{~min}$, dried, and blocked with $10 \%$ NGS for 30 min at RT. Primary antibody diluted in 1\% BSA in PBS was added to the sections and incubated in a humidified chamber overnight at $4{ }^{\circ} \mathrm{C}$. Sections were washed three times with PBS and incubated in secondary antibody (goat anti-rabbit Alexa-594 nm, A11037, Thermo Fisher Scientific, Darmstadt, Germany) in 1\% BSA in PBS in a humidified chamber for $1 \mathrm{~h}$ at RT. Signal intensities were quantified with ImageJ software. Primary antibodies specific for human (KR71) and mouse (KR47) collagen XIV were produced as described previously [29]. 


\subsection{Immunohistochemical Staining}

Immunohistochemistry was performed using human melanoma sections. Sections were fixed with ice-cold acetone for $8 \mathrm{~min}$, blocked with 5\% BSA in $0.05 \%$ TBS-Tween for $1 \mathrm{~h}$, and incubated overnight with the primary antibody to MMP14 (Chemicon, MAB3328, 1:200, Nürnberg, Germany). Secondary antibodies were detected using the DCS detection Line (DCS Innovative Diagnostic Systems, AD000RP, Hamburg, Germany) and Fast Red as substrate (XBioGenex, HK182-5KE, Fremont, CA, USA).

\subsection{RNA Isolation, RT-PCR, and Real-Time PCR}

RNA was isolated from primary fibroblast cells, lysed with RNAzolTM B (WAK-CS105, WAK-Chemie, Taunus, Germany), and incubated on ice for $5 \mathrm{~min}$. Cells were scratched and inverted with phenol-chloroform (X085.1, Roth, Karlsruhe, Germany) for $15 \mathrm{~s}$. After incubation on ice for $3 \mathrm{~min}$, samples were centrifuged at $16,000 \times \mathrm{g}$ for $15 \mathrm{~min}$ at $4{ }^{\circ} \mathrm{C}$, and RNA was precipitated by adding isopropanol to the supernatant. Samples were incubated overnight at $-80{ }^{\circ} \mathrm{C}$ and centrifuged for $10 \mathrm{~min}$ at $16,000 \times \mathrm{g}$ at $4{ }^{\circ} \mathrm{C}$. The pellet was washed with $70 \% \mathrm{EtOH}$ and resuspended in $\mathrm{H}^{2} \mathrm{O}$. Reverse transcription and quantitative real-time PCR were performed as described previously [14]. Primers for the amplification of COL6A1 and S26 have been previously described [10,58]. Primers for COL14A1 were for $5^{\prime}$ TGGTGGAGAGCCTGACCCGG 3'; rev 5' GCATCCCACCTGACGCGCAT 3'; accession number: BC138345.

\subsection{Statistics}

Statistical analysis was performed using GraphPad Prism version 7.05 for Windows (GraphPad Software, La Jolla, CA, USA, www.graphpad.com). The student's $t$-test was performed for data analysis with $p<0.5$ considered as statistically significant

Supplementary Materials: The following are available online at https:/ / www.mdpi.com/article/ 10.3390/ijms222212276/s1.

Author Contributions: Conceptualization, C.M. and P.Z.; methodology, E.P., M.K. (Maike Kümper), J.E.F., F.M., M.K. (Manuel Koch) and P.Z.; validation, E.P., M.K. (Maike Kümper), J.E.F., J.Z. and P.Z.; formal analysis, E.P., M.K. (Maike Kümper), J.E.F., F.M., M.K. (Manuel Koch) and P.Z.; investigation, E.P., M.K. (Maike Kümper), J.E.F., J.Z. and P.Z.; resources, C.M., M.K. (Manuel Koch) and P.Z.; data curation, E.P. and P.Z.; writing—original draft preparation, E.P., M.K. (Maike Kümper), J.E.F. and P.Z.; writing — review and editing, E.P. and P.Z.; visualization, E.P. and P.Z.; supervision, P.Z.; project administration, P.Z.; funding acquisition, C.M. and P.Z. All authors have read and agreed to the published version of the manuscript.

Funding: This work was supported by the Deutsche Forschungsgemeinschaft-Project-ID 73111208 -SFB829 (B4) to P.Z. and C.M.; the German Cancer Aid (70114473) to P.Z., the Deutsche Forschungsgemeinschaft-Forschergruppe FOR2722 to M.Ko., and the German Cancer Aid through a Mildred Scheel Nachwuchszentrum Grant (70113307) to J.E.F.

Institutional Review Board Statement: Animal experiments, from which we obtained the material used herein, were performed following German Regulations for Welfare of Laboratory Animals and with approval by the LANUV NRW (NRW authorization 84-02.04.2016.A012). Human material was collected according to the study protocol conformed to the ethical guidelines of the 1975 Declaration of Helsinki and was approved by the Ethics Committee of the Medical Faculty of the University of Cologne (Registration No. 08-144). Informed consent has been obtained. Human material was provided by the Central Project (Z4) of the SFB829.

Informed Consent Statement: Informed consent was obtained from all subjects involved in the study.

Data Availability Statement: The data presented in this study are available on request from the corresponding author. The data are not publicly available due to privacy.

Conflicts of Interest: The authors declare no conflict of interest. 


\section{References}

1. Stetler-Stevenson, W.G.; Liotta, L.A.; Kleiner, D.E., Jr. Extracellular matrix 6: Role of matrix metalloproteinases in tumor invasion and metastasis. Faseb J. 1993, 7, 1434-1441. [CrossRef]

2. Murphy, G.; Nagase, H. Progress in matrix metalloproteinase research. Mol. Aspects Med. 2008, 29, 290-308. [CrossRef] [PubMed]

3. Sato, H.; Takino, T.; Kinoshita, T.; Imai, K.; Okada, Y.; Stetler Stevenson, W.G.; Seiki, M. Cell surface binding and activation of gelatinase A induced by expression of membrane-type-1-matrix metalloproteinase (MT1-MMP). FEBS Lett. 1996, 385, 238-240. [CrossRef]

4. Hillebrand, L.E.; Wickberg, S.M.; Gomez-Auli, A.; Follo, M.; Maurer, J.; Busch, H.; Boerries, M.; Reinheckel, T. MMP14 empowers tumor-initiating breast cancer cells under hypoxic nutrient-depleted conditions. FASEB J. 2019, 33, 4124-4140. [CrossRef]

5. Kasurinen, A.; Gramolelli, S.; Hagström, J.; Laitinen, A.; Kokkola, A.; Miki, Y.; Lehti, K.; Yashiro, M.; Ojala, P.M.; Böckelman, C.; et al. High tissue MMP14 expression predicts worse survival in gastric cancer, particularly with a low PROX1. Cancer Med. 2019, 8, 6995-7005. [CrossRef]

6. Jiang, W.G.; Davies, G.; Martin, T.A.; Parr, C.; Watkins, G.; Mason, M.D.; Mansel, R.E. Expression of membrane type-1 matrix metalloproteinase, MT1-MMP in human breast cancer and its impact on invasiveness of breast cancer cells. Int. J. Mol. Med. 2006, 17, 583-590. [CrossRef] [PubMed]

7. Gutierrez-Fernandez, A.; Soria-Valles, C.; Osorio, F.G.; Gutierrez-Abril, J.; Garabaya, C.; Aguirre, A.; Fueyo, A.; Fernandez-Garcia, M.S.; Puente, X.S.; Lopez-Otin, C. Loss of MT1-MMP causes cell senescence and nuclear defects which can be reversed by retinoic acid. EMBO J. 2015, 34, 1875-1888. [CrossRef] [PubMed]

8. Holmbeck, K.; Bianco, P.; Caterina, J.; Yamada, S.; Kromer, M.; Kuznetsov, S.A.; Mankani, M.; Robey, P.G.; Poole, A.R.; Pidoux, I.; et al. MT1-MMP-deficient mice develop dwarfism, osteopenia, arthritis, and connective tissue disease due to inadequate collagen turnover. Cell 1999, 99, 81-92. [CrossRef]

9. Zhou, Z.; Apte, S.S.; Soininen, R.; Cao, R.; Baaklini, G.Y.; Rauser, R.W.; Wang, J.; Cao, Y.; Tryggvason, K. Impaired endochondral ossification and angiogenesis in mice deficient in membrane-type matrix metalloproteinase I. Proc. Natl. Acad. Sci. USA 2000, 97, 4052-4057. [CrossRef] [PubMed]

10. Zigrino, P.; Ayachi, O.; Schild, A.; Kaltenberg, J.; Zamek, J.; Nischt, R.; Koch, M.; Mauch, C. Loss of epidermal MMP-14 expression interferes with angiogenesis but not with re-epithelialization. Eur. J. Cell. Biol. 2012, 91, 748-756. [CrossRef]

11. Klose, A.; Zigrino, P.; Mauch, C. Monocyte/macrophage MMP-14 modulates cell infiltration and T-cell attraction in contact dermatitis but not in murine wound healing. Am. J. Pathol. 2013, 182, 755-764. [CrossRef]

12. Taylor, S.H.; Yeung, C.Y.; Kalson, N.S.; Lu, Y.; Zigrino, P.; Starborg, T.; Warwood, S.; Holmes, D.F.; Canty-Laird, E.G.; Mauch, C.; et al. Matrix metalloproteinase 14 is required for fibrous tissue expansion. Elife 2015, 4, e09345. [CrossRef] [PubMed]

13. Zigrino, P.; Brinckmann, J.; Niehoff, A.; Lu, Y.; Giebeler, N.; Eckes, B.; Kadler, K.E.; Mauch, C. Fibroblast-Derived MMP-14 Regulates Collagen Homeostasis in Adult Skin. J. Invest. Dermatol. 2016, 136, 1575-1583. [CrossRef] [PubMed]

14. Pach, E.; Brinckmann, J.; Rübsam, M.; Kümper, M.; Mauch, C.; Zigrino, P. Fibroblast MMP14-Dependent Collagen Processing Is Necessary for Melanoma Growth. Cancers 2021, 13, 1984. [CrossRef] [PubMed]

15. Gordon, M.K.; Hahn, R.A. Collagens. Cell Tissue Res. 2010, 339, 247-257. [CrossRef]

16. Beachley, V.Z.; Wolf, M.T.; Sadtler, K.; Manda, S.S.; Jacobs, H.; Blatchley, M.R.; Bader, J.S.; Pandey, A.; Pardoll, D.; Elisseeff, J.H. Tissue matrix arrays for high-throughput screening and systems analysis of cell function. Nat. Methods 2015, 12, 1197-1204. [CrossRef]

17. Pickering, J.G. Regulation of vascular cell behavior by collagen: Form is function. Circ. Res. 2001, 88, 458-459. [CrossRef] [PubMed]

18. Hamano, Y.; Zeisberg, M.; Sugimoto, H.; Lively, J.C.; Maeshima, Y.; Yang, C.; Hynes, R.O.; Werb, Z.; Sudhakar, A.; Kalluri, R. Physiological levels of tumstatin, a fragment of collagen IV alpha3 chain, are generated by MMP-9 proteolysis and suppress angiogenesis via alphaV beta3 integrin. Cancer Cell 2003, 3, 589-601. [CrossRef]

19. Ramchandran, R.; Dhanabal, M.; Volk, R.; Waterman, M.J.; Segal, M.; Lu, H.; Knebelmann, B.; Sukhatme, V.P. Antiangiogenic activity of restin, NC10 domain of human collagen XV: Comparison to endostatin. Biochem. Biophys. Res. Commun. 1999, 255, 735-739. [CrossRef]

20. Hong, J.; Chu, M.; Qian, L.; Wang, J.; Guo, Y.; Xu, D. Fibrillar Type I Collagen Enhances the Differentiation and Proliferation of Myofibroblasts by Lowering $\alpha 2 \beta 1$ Integrin Expression in Cardiac Fibrosis. Biomed. Res. Int. 2017, 2017, 1790808. [CrossRef] [PubMed]

21. Somaiah, C.; Kumar, A.; Mawrie, D.; Sharma, A.; Patil, S.D.; Bhattacharyya, J.; Swaminathan, R.; Jaganathan, B.G. Collagen Promotes Higher Adhesion, Survival and Proliferation of Mesenchymal Stem Cells. PLoS ONE 2015, 10, e0145068. [CrossRef]

22. Xu, S.; Xu, H.; Wang, W.; Li, S.; Li, H.; Li, T.; Zhang, W.; Yu, X.; Liu, L. The role of collagen in cancer: From bench to bedside. J. Transl. Med. 2019, 17, 309. [CrossRef] [PubMed]

23. Theocharidis, G.; Connelly, J.T. Minor collagens of the skin with not so minor functions. J. Anat. 2019, 235, 418-429. [CrossRef]

24. Lu, P.; Weaver, V.M.; Werb, Z. The extracellular matrix: A dynamic niche in cancer progression. J. Cell Biol. 2012, 196, 395-406. [CrossRef] [PubMed]

25. Fang, M.; Yuan, J.; Peng, C.; Li, Y. Collagen as a double-edged sword in tumor progression. Tumour. Biol. 2014, 35, $2871-2882$. [CrossRef] [PubMed] 
26. Winkler, J.; Abisoye-Ogunniyan, A.; Metcalf, K.J.; Werb, Z. Concepts of extracellular matrix remodelling in tumour progression and metastasis. Nat. Commun. 2020, 11, 5120. [CrossRef]

27. Knapinska, A.M.; Fields, G.B. The Expanding Role of MT1-MMP in Cancer Progression. Pharmaceuticals 2019, 12, 77. [CrossRef] [PubMed]

28. Gerecke, D.R.; Meng, X.; Liu, B.; Birk, D.E. Complete primary structure and genomic organization of the mouse Col14a1 gene. Matrix Biol 2004, 22, 595-601. [CrossRef]

29. Ansorge, H.L.; Meng, X.; Zhang, G.; Veit, G.; Sun, M.; Klement, J.F.; Beason, D.P.; Soslowsky, L.J.; Koch, M.; Birk, D.E. Type XIV Collagen Regulates Fibrillogenesis: Premature collagen fibril growth and tissue dysfunction in null mice. J. Biol. Chem. 2009, 284, 8427-8438. [CrossRef]

30. Tzortzaki, E.G.; Tischfield, J.A.; Sahota, A.; Siafakas, N.M.; Gordon, M.K.; Gerecke, D.R. Expression of FACIT collagens XII and XIV during bleomycin-induced pulmonary fibrosis in mice. Anat. Rec. A Discov. Mol. Cell Evol. Biol. 2003, 275, 1073-1080. [CrossRef]

31. Tzortzaki, E.G.; Koutsopoulos, A.V.; Dambaki, K.I.; Lambiri, I.; Plataki, M.; Gordon, M.K.; Gerecke, D.R.; Siafakas, N.M. Active remodeling in idiopathic interstitial pneumonias: Evaluation of collagen types XII and XIV. J. Histochem. Cytochem. 2006, 54, 693-700. [CrossRef] [PubMed]

32. Kong, R.; Liu, H.; Shi, Y.; Man, Q.; Liu, S. COL14A1 promotes self-renewal of human liver cancer stem cells through activation of ERK signaling. J. Bio-X Res. 2021, 4, 10-17. [CrossRef]

33. Agarwal, P.; Zwolanek, D.; Keene, D.R.; Schulz, J.N.; Blumbach, K.; Heinegård, D.; Zaucke, F.; Paulsson, M.; Krieg, T.; Koch, M.; et al. Collagen XII and XIV, new partners of cartilage oligomeric matrix protein in the skin extracellular matrix suprastructure. J. Biol. Chem. 2012, 287, 22549-22559. [CrossRef] [PubMed]

34. van Kempen, L.C.; van Muijen, G.N.; Ruiter, D.J. Stromal responses in human primary melanoma of the skin. Front Biosci. 2005, 10, 2922-2931. [CrossRef] [PubMed]

35. Hofmann, U.B.; Westphal, J.R.; Zendman, A.J.; Becker, J.C.; Ruiter, D.J.; van Muijen, G.N. Expression and activation of matrix metalloproteinase-2 (MMP-2) and its co-localization with membrane-type 1 matrix metalloproteinase (MT1-MMP) correlate with melanoma progression. J. Pathol. 2000, 191, 245-256. [CrossRef]

36. Miskolczi, Z.; Smith, M.P.; Rowling, E.J.; Ferguson, J.; Barriuso, J.; Wellbrock, C. Collagen abundance controls melanoma phenotypes through lineage-specific microenvironment sensing. Oncogene 2018, 37, 3166-3182. [CrossRef] [PubMed]

37. Liu, J.; Tan, Y.; Zhang, H.; Zhang, Y.; Xu, P.; Chen, J.; Poh, Y.C.; Tang, K.; Wang, N.; Huang, B. Soft fibrin gels promote selection and growth of tumorigenic cells. Nat. Mater. 2012, 11, 734-741. [CrossRef]

38. Li, Y.; Fanous, M.J.; Kilian, K.A.; Popescu, G. Quantitative phase imaging reveals matrix stiffness-dependent growth and migration of cancer cells. Sci. Rep. 2019, 9, 248. [CrossRef]

39. Henriet, P.; Zhong, Z.D.; Brooks, P.C.; Weinberg, K.I.; DeClerck, Y.A. Contact with fibrillar collagen inhibits melanoma cell proliferation by up-regulating p27KIP1. Proc. Natl. Acad. Sci. USA 2000, 97, 10026-10031. [CrossRef]

40. Ahmadzadeh, H.; Webster, M.R.; Behera, R.; Jimenez Valencia, A.M.; Wirtz, D.; Weeraratna, A.T.; Shenoy, V.B. Modeling the two-way feedback between contractility and matrix realignment reveals a nonlinear mode of cancer cell invasion. Proc. Natl. Acad. Sci. USA 2017, 114, E1617-E1626. [CrossRef]

41. Ju, R.J.; Stehbens, S.J.; Haass, N.K. The Role of Melanoma Cell-Stroma Interaction in Cell Motility, Invasion, and Metastasis. Front. Med. 2018, 5, 307. [CrossRef] [PubMed]

42. Gobin, E.; Bagwell, K.; Wagner, J.; Mysona, D.; Sandirasegarane, S.; Smith, N.; Bai, S.; Sharma, A.; Schleifer, R.; She, J.X. A pan-cancer perspective of matrix metalloproteases (MMP) gene expression profile and their diagnostic/prognostic potential. BMC Cancer 2019, 19, 581. [CrossRef] [PubMed]

43. Friedl, P.; Wolf, K. Proteolytic interstitial cell migration: A five-step process. Cancer Metastasis Rev. 2009, 28, 129-135. [CrossRef] [PubMed]

44. Bonaventure, J.; Domingues, M.J.; Larue, L. Cellular and molecular mechanisms controlling the migration of melanocytes and melanoma cells. Pigment Cell Melanoma Res. 2013, 26, 316-325. [CrossRef]

45. Berthod, F.; Germain, L.; Guignard, R.; Lethias, C.; Garrone, R.; Damour, O.; van der Rest, M.; Auger, F.A. Differential expression of collagens XII and XIV in human skin and in reconstructed skin. J. Invest. Dermatol. 1997, 108, 737-742. [CrossRef]

46. Ruehl, M.; Erben, U.; Schuppan, D.; Wagner, C.; Zeller, A.; Freise, C.; Al-Hasani, H.; Loesekann, M.; Notter, M.; Wittig, B.M.; et al. The elongated first fibronectin type III domain of collagen XIV is an inducer of quiescence and differentiation in fibroblasts and preadipocytes. J. Biol. Chem. 2005, 280, 38537-38543. [CrossRef]

47. Luo, Y.; Sinkeviciute, D.; He, Y.; Karsdal, M.; Henrotin, Y.; Mobasheri, A.; Önnerfjord, P.; Bay-Jensen, A. The minor collagens in articular cartilage. Protein Cell 2017, 8, 560-572. [CrossRef]

48. Paetow, C. Collagen XIV Reduces Proliferation of Human CD44-Positive Tumour Cell Lines. Ph.D. Thesis, Freie University, Berlin, Germany, 2009. [CrossRef]

49. Freise, C.; Bobb, V.; Querfeld, U. Collagen XIV and a related recombinant fragment protect human vascular smooth muscle cells from calcium-/phosphate-induced osteochondrocytic transdifferentiation. Exp. Cell Res. 2017, 358, 242-252. [CrossRef]

50. Tao, G.; Levay, A.K.; Peacock, J.D.; Huk, D.J.; Both, S.N.; Purcell, N.H.; Pinto, J.R.; Galantowicz, M.L.; Koch, M.; Lucchesi, P.A.; et al. Collagen XIV is important for growth and structural integrity of the myocardium. J. Mol. Cell Cardiol. 2012, 53, 626-638. [CrossRef] 
51. Shain, A.H.; Bastian, B.C. From melanocytes to melanomas. Nat. Rev. Cancer 2016, 16, 345-358. [CrossRef]

52. Riker, A.I.; Enkemann, S.A.; Fodstad, O.; Liu, S.; Ren, S.; Morris, C.; Xi, Y.; Howell, P.; Metge, B.; Samant, R.S.; et al. The gene expression profiles of primary and metastatic melanoma yields a transition point of tumor progression and metastasis. BMC Med. Genomics 2008, 1, 13. [CrossRef]

53. Fidler, I.J. Selection of successive tumour lines for metastasis. Nat. New Biol. 1973, 242, 148-149. [CrossRef] [PubMed]

54. Bald, T.; Quast, T.; Landsberg, J.; Rogava, M.; Glodde, N.; Lopez-Ramos, D.; Kohlmeyer, J.; Riesenberg, S.; van den BoornKonijnenberg, D.; Hömig-Hölzel, C.; et al. Ultraviolet-radiation-induced inflammation promotes angiotropism and metastasis in melanoma. Nature 2014, 507, 109-113. [CrossRef] [PubMed]

55. Tobys, D.; Kowalski, L.M.; Cziudaj, E.; Müller, S.; Zentis, P.; Pach, E.; Zigrino, P.; Blaeske, T.; Höning, S. Inhibition of clathrinmediated endocytosis by knockdown of AP-2 leads to alterations in the plasma membrane proteome. Traffic 2021, 22, 6-22. [CrossRef] [PubMed]

56. Kulak, N.A.; Pichler, G.; Paron, I.; Nagaraj, N.; Mann, M. Minimal, encapsulated proteomic-sample processing applied to copy-number estimation in eukaryotic cells. Nat. Methods 2014, 11, 319-324. [CrossRef] [PubMed]

57. Irmak, D.; Fatima, A.; Gutiérrez-Garcia, R.; Rinschen, M.M.; Wagle, P.; Altmüller, J.; Arrigoni, L.; Hummel, B.; Klein, C.; Frese, C.K.; et al. Mechanism suppressing H3K9 trimethylation in pluripotent stem cells and its demise by polyQ-expanded huntingtin mutations. Hum. Mol. Genet. 2018, 27, 4117-4134. [CrossRef]

58. Chakraborty, A.; Barajas, S.; Lammoglia, G.M.; Reyna, A.J.; Morley, T.S.; Johnson, J.A.; Scherer, P.E.; Rutkowski, J.M. Vascular Endothelial Growth Factor-D (VEGF-D) Overexpression and Lymphatic Expansion in Murine Adipose Tissue Improves Metabolism in Obesity. Am. J. Pathol. 2019, 189, 924-939. [CrossRef] [PubMed] 